\title{
PROGNOSTIC FACTORS IN LOCALLY ADVANCED COLON CANCER TREATED BY EXTENDED RESECTION
}

\author{
René A.C. Vieira, Ademar Lopes, Paulo A.C. Almeida, Benedito M. Rossi, Wilson \\ T. Nakagawa, Fabio O. Ferreira and Celso A. Melo
}

VIEIRA RAC et al. Prognostic factors in locally advanced colon cancer treated by extended resection. Rev. Hosp. Clín. Fac. Med. S. Paulo 59(6):361-368, 2004.

The impact of clinical, pathologic, and surgical variables on the postoperative morbidity, mortality, and survival of patients undergoing extended resections of colon carcinoma were evaluated.

METHODS: The medical records of 95 patients who underwent extended resections for colon carcinoma between 1953 and 1996 were reviewed. In all cases, in addition to colectomy, 1 or more organs and/or structures were resected en bloc due to a macroscopically based suspicion of tumor invasion. The clinical, pathologic, and surgical parameters were analyzed. Overall survival rates were analyzed according to the method of Kaplan and Meier. Multivariate analysis was performed using the Cox proportional hazards model.

RESULTS: Eighty-six patients were treated by curative surgeries and the remaining by palliative resections. Invasion of the organs and/or adjacent structures and regional lymph nodes was found microscopically in 48 and 31 patients, respectively. The median follow-up without postoperative mortality was 47.7 months. The 5-year overall survival rates was $52.6 \%$. The 5-year overall survival rates for patients undergoing curative and palliative surgeries was $58.3 \%$ and $0 \%$, respectively. The mean survival time in the palliative surgery group was 3.1 months. Multivariate analysis showed that Karnofsky performance status was strongly related to the risk of postoperative complications $(P=.01)$, and postoperative deaths were associated with the type of surgery and Karnofsky performance status at the time of admission $(P=.001)$.

CONCLUSIONS: Some patients with locally advanced colon adenocarcinomas undergoing extended resections have a 5-year overall survival rates of $58.3 \%$. Patients could benefit from palliative-intent procedures, but these measures should cautiously be indicated and avoided in patients with low Karnofsky performance status due to high rates of postoperative mortality and poor survival.

KEYWORDS: Extended surgery. En bloc resection. Colon cancer. Morbidity. Mortality. Prognosis.

The term, locally advanced colorectal cancer, refers to tumors infiltrating or adherent to adjacent organs and/or structures in patients without distant metastases. Frequently considered an uncurable disease, locally advanced colorectal cancer represent $5 \%$ to $22 \%$ of all colorectal carcinomas. $^{1-5}$

In the USA, there are an estimated nearly 130,000 new cases per year of colorectal carcinoma, and 6,500 cases are locally advanced. ${ }^{6}$ Surgery still re- mains the only curative treatment for colon cancer. Radiation and chemotherapy do not cure locally advanced colon cancer. ${ }^{7}$

Extended or multivisceral resection is the type of procedure in which, in addition to the standard operation,

From the Department of Pelvic Surgery and Pathology, Hospital do Câncer A. C. Camargo, Fundação Antonio Prudente - São Paulo/SP, Brasil.

E-mail: lopesa@uol.com.br

Received for publication on May 17, 2004. Accepted for publication on July 16, 2004. adherent organs and/or structures are resected en bloc. ${ }^{8}$ The rational for multivisceral resections is that microscopic infiltration of the organs and/ or adjacent structures can not be ascertained preoperatively or even intraoperatively. ${ }^{9}$ Furthermore, the dissection between the colonic tumor and the adjacent structures can seed neoplastic cells in the peritoneal surface, resulting in a poor prognosis. ${ }^{1,2,11,12}$ Thus, this practice should be avoided. 
Extended surgeries are recommended because good local control of colorectal cancer can be achieved with results for 5-year survival of rates of $33 \%$ to $79 \%$ in different series ., $2,11,13,14$ Despite the good survival rates, patients undergoing extended resections experience considerable postoperative mortality and morbidity., ${ }^{3,13,15}$ With the improvement of postoperative care and surgical technique, postoperative mortality and morbidity rates have decreased and are comparable to the rates achieved with standard or nonextended resections. ${ }^{11,16}$

The aim of this study was to evaluate the clinical, pathologic, and surgical prognostic factors in patients with locally advanced colon cancer treated with surgery.

\section{PATIENTS AND METHODS}

The medical records of 95 patients with locally advanced colon carcinoma undergoing extended resections from 1953 to 1996 were reviewed. Extended resection was defined as an en bloc surgery of the primary colon tumor together with 1 or more organs and/or structures that are macroscopically adherent to the tumor-bearing bowel segment. The presence of macroscopic residual tumor ( $\mathrm{R} 2$ resection), positive microscopic margins ( $\mathrm{R} 1 \mathrm{re}$ section), or abdominal or systemic disease indicated the palliative-intent procedures. The absence of these elements (R0 resection) indicated the curative-intent surgeries.

Clinical and laboratory variables were studied, including age, gender, Karnofsky performance status at admission, tumor location, preoperative serum albumin, and hemoglobin level.

Surgical records were searched for type of surgery (curative or palliative), date of the procedure, previous laparotomy, operative time, number of resected organs and/or structures, hos- pital stay, and decade of the surgery. Data related to postoperative complications, as well as the date and cause of death were also collected. All slides were reviewed by the same pathologist.

Histological subtypes, tumor grade, microscopic margins, clinical and pathological stages (pTNM-1997), primary tumor penetration (pT), lymph node status $(\mathrm{pN})$, perineural infiltration, and lymphatic and vascular embolization were evaluated. The outcome was classified as follows: alive with no evidence of disease; dead by cancer or related causes, including treatment; dead without cancer (causes not related); and lost to follow-up. The specific cancer mortality was evaluated. The survival analysis began on the date of the surgery and finished on June $30^{\text {th }} 1999$.

Postoperative deaths were those occurred during the hospitalization or readmission due to short-term complications. We considered the case lost to follow-up when the patient did not return within a time equal or longer than 2 times the recommended time interval.

\section{Statistics}

The chi-square and Fisher exact tests were used to compare variables. The multiple logistic regression model was used to evaluate complications and postoperative death risk. The actuarial survival estimates were calculated according to the Kaplan \& Meyer method, and the multifactorial relative risk of death was analyzed with the Cox proportional hazards model using a significance level of $P$ $<.05$. A variable was selected for multivariate analysis when $P<.10$. Postoperative mortality was not excluded from the analysis. The SPSS ${ }^{\circledR}$ program for Windows ${ }^{\mathrm{TM}} 8.0$ was used.

\section{RESULTS}

Five patients who had surgery dur- ing the 1950s were evaluated, 7 with surgery in the 1960s, 21 in 1970s, 35 in 1980s, and 27 in 1990s. Patient ages ranged from 15 to 84 years (median $=56$ years). Of the total of $95 \mathrm{pa}-$ tients, 48 were male and 86 were Caucasian. The disease evolution time ranged from 1 day, for a patient with an acute abdomen, to 60 months (mean $=11.1$ months). The cecum and sigmoid were the most frequent tumor locations.

The most common signs and symptoms were pain (71), weight loss (69), rectal bleeding (38), change in bowel habits (52), tumor (53), mucorrhea (9), fever (9), fistula (7), vaginal bleeding (4), and pneumaturia (3). A palpable tumor at the physical examination was found in 57 patients. Seventy-one patients had no previous treatment, and 24 had been already undergone laparotomy, with the tumor considered unresectable. Curative surgery (R0) was performed in 86 cases. The operative time ranged from 2 to 12.2 hours (mean $=6$ hours). Intra-operative blood transfusion was necessary in 79 patients $($ mean $=900 \mathrm{~mL}$ ). The hospital stay ranged from 1 day (1 patient who died during the surgery) to 70 days ( mean $=15.5 ;$ median $=11$ days $)$. The number of organs and/or structures resected en bloc was 1 (40 patients), 2 (38 patients); 3 (11 patients); 4 (5 patients), and 5 (1 patients). Abdominal wall muscles were the most frequently resected structures (36), followed by the small bowel (29) and bladder (18).

Regarding the types of tumors found, 61 patients had pure adenocarcinoma, 27 mucinous, and 7 other histologic subtypes. Regarding tumor differentiation, 21 were well differentiated; 54 moderately differentiated, and 20 poorly differentiated.

Microscopic involvement of adjacent organs and/or structures occurred in 48 patients. In 1 case, it was not possible to differentiate inflammatory adhesion from tumor infiltration. The 
Table 1 - Tumor penetration and lymph node status in patients undergoing extended resections due to colon cancer.

\begin{tabular}{|c|c|c|c|c|c|c|}
\hline $\begin{array}{l}\text { Tumor Penetration } \\
\text { (pT) }\end{array}$ & $\begin{array}{l}\text { Lymph node } \\
\text { status (pN0) }\end{array}$ & $\begin{array}{l}\text { Lymph node } \\
\text { status (pN1) }\end{array}$ & $\begin{array}{l}\text { Lymph node } \\
\text { status (pN2) }\end{array}$ & $\begin{array}{l}\text { Lymph node } \\
\text { status }(\mathrm{pNx})\end{array}$ & $\begin{array}{l}\text { Lymph node } \\
\text { status }(\mathrm{pN}+)\end{array}$ & Total \\
\hline$\overline{\mathrm{pT} 2}$ & 3 & - & - & - & - & 3 \\
\hline pT3 & 27 & 11 & 5 & - & 16 & 43 \\
\hline pT4 & 28 & 7 & 8 & 5 & 15 & 48 \\
\hline pTx & - & - & - & 1 & - & 1 \\
\hline Total & 58 & 18 & 13 & 6 & 31 & 95 \\
\hline
\end{tabular}

number of dissected lymph nodes ranged from 3 to 72 nodes (mean $=$ 21.4 nodes). In 6 cases, the lymph node status could not be established. In 58 patients, lymph node metastasis was absent (pNO).

The tumor penetration (pT) and lymph node status $(\mathrm{pN})$ parameters are listed in Table 1. Table 2 shows the relationship between resected organs and/or structures and the histologic infiltration.

Twenty-two deaths occurred, and morbidity related to extended resections was observed in 53 patients. The main complications were cardiovascular (18), wound infection (16), intestinal fistula (6), sepsis (6), deep venous thrombosis (3), wall dehiscence (3), urinary fistula (2), and hernia (2). Table 3 shows the relative risk of complication and death according to selected variables. Karnofsky performance status $(P$ $=.02$ ) and type of surgery (curative vs palliative) $(P=.004)$ were independent prognostic factors for postoperative death rates in the multivariate analysis $(P=.001)$ (Table 3).

Patients treated after 1980 had $39 \%$ fewer postoperative complications. Postoperative mortality decreased from $42.9 \%$ in the 1950 s to $7.4 \%$ in the 1990 s $(P=.09)$. The postoperative death risk decreased $57 \%$ for patients treated after 1980.

Patients who underwent palliative surgeries had higher complication rates $(77.8 \%$ vs $53.5 \%)$ and postopera-

Table 2 - Resected organ and/or structure, tumor penetration, and 5-year overall survival rates in patients undergoing extended resections due to colon cancer.

\begin{tabular}{lccc}
\hline $\begin{array}{l}\text { Resected organ and/ } \\
\text { or structure }\end{array}$ & $\begin{array}{c}\text { Number of } \\
\text { patients }\end{array}$ & $\begin{array}{c}\text { Tumor penetration } \\
\text { staging }(\mathrm{pT} \text { 4) }\end{array}$ & 5-year survival (\%) \\
\hline Abdominal wall & 36 & 18 & 57.7 \\
Small bowel & 29 & 10 & 57.7 \\
Bladder & 18 & 6 & 54.2 \\
Ovary & 12 & 3 & 41.7 \\
Uterus & 10 & 6 & 37.5 \\
Duodenum & 8 & 2 & 56.2 \\
Stomach & 10 & 2 & 56.2 \\
Kidney & 6 & 2 & 83.3 \\
Gonadal vessels & 4 & 2 & 100.0 \\
Pancreas & 3 & 1 & 100.0 \\
Liver & 3 & 2 & 06.7 \\
Prostate & 1 & 0 & 0 \\
Ureter & 1 & 0 & - \\
Total & 95 & 48 & \\
\hline
\end{tabular}

Table 3 - Relative risk of postoperative complication and death according to selected variables in patients undergoing extended resections due to colon cancer.

\begin{tabular}{|c|c|c|c|c|c|c|c|c|}
\hline Variable & Category & $\begin{array}{c}\text { Number of } \\
\text { patients }\end{array}$ & $\begin{array}{l}\text { Odds } \\
\text { ratio }\end{array}$ & $\begin{array}{c}\text { Complication } \\
\text { confidence } \\
\text { interval }\end{array}$ & $P$ & $\begin{array}{l}\text { Odds } \\
\text { ratio }\end{array}$ & $\begin{array}{c}\text { Death } \\
\text { confidence } \\
\text { interval }\end{array}$ & $P$ \\
\hline Karnofsky performance status & $\begin{array}{l}80 \text { to } 100 \\
60 \text { to } 70 \\
<\text { or }=50\end{array}$ & $\begin{array}{r}41 \\
48 \\
6\end{array}$ & $\begin{array}{c}1.00 \\
2.82+\end{array}$ & $\begin{array}{c}\text { ref } \\
1.22-6.54\end{array}$ & .01 & $\begin{array}{l}1.00 \\
1.44 \\
9.71\end{array}$ & $\begin{array}{c}\text { ref } \\
0.50-4.15 \\
1.48-63.80\end{array}$ & .02 \\
\hline Albumin* & $\begin{array}{l}>\text { or }=3.5 \mathrm{~g} \% \\
\quad<3.5 \mathrm{~g} \%\end{array}$ & $\begin{array}{l}23 \\
71\end{array}$ & $\begin{array}{l}1.00 \\
2.53\end{array}$ & $\begin{array}{c}\text { ref } \\
0.96-6.65\end{array}$ & .05 & $\begin{array}{l}1.00 \\
1.13\end{array}$ & $\begin{array}{c}\text { ref } \\
0.36-3.51\end{array}$ & .82 \\
\hline Pre-operative & $>=10 \mathrm{~g} \%$ & 54 & 1.00 & ref & .19 & 1.00 & ref & .08 \\
\hline Hemoglobin & $<10 \mathrm{~g} \%$ & 41 & 1.73 & $0.76-3.97$ & & 2.32 & $0.88-6.14$ & \\
\hline $\begin{array}{l}\text { Surgical status } \\
\text { on admission }\end{array}$ & $\begin{array}{c}\text { Intact } \\
\text { Previous laparotomy }\end{array}$ & $\begin{array}{l}71 \\
24\end{array}$ & $\begin{array}{l}1.00 \\
1.84\end{array}$ & $\begin{array}{c}\text { ref } \\
0.67-4.84\end{array}$ & .21 & $\begin{array}{l}1.00 \\
1.15\end{array}$ & $\begin{array}{c}\text { ref } \\
0.39-3.37\end{array}$ & .80 \\
\hline $\begin{array}{l}\text { Type of } \\
\text { surgery }\end{array}$ & $\begin{array}{l}\text { Curative } \\
\text { Palliative }\end{array}$ & $\begin{array}{c}86 \\
9\end{array}$ & $\begin{array}{l}1.00 \\
3.04\end{array}$ & $\begin{array}{c}\text { ref } \\
0.60-15.50\end{array}$ & .18 & $\begin{array}{l}1.00 \\
8.75\end{array}$ & $\begin{array}{c}\text { ref } \\
1.97-38.76\end{array}$ & .004 \\
\hline $\begin{array}{l}\text { Number of resected } \\
\text { organs }\end{array}$ & $\begin{array}{c}1 \\
2 \text { to } 5\end{array}$ & $\begin{array}{l}40 \\
55\end{array}$ & $\begin{array}{l}1.00 \\
0.88\end{array}$ & $\begin{array}{c}\text { ref } \\
0.39-2.02\end{array}$ & .77 & $\begin{array}{l}1.00 \\
0.84\end{array}$ & $\begin{array}{c}\text { ref } \\
0.32-2.20\end{array}$ & .71 \\
\hline
\end{tabular}

*Cases without information were excluded from analysis; + fair and bad association; ref = reference. 
tive death $(66.7 \%$ vs $18.6 \%)$ compared to curative procedures. The univariate analysis showed that cardiopulmonary complications $(P=.001)$ and anastomosis dehiscences with sepsis $(P$ $=.009$ ) were also related to high rates of postoperative mortality.

The follow-up ranged from 1 to 295.2 months $($ mean $=53.9 ;$ median $=$ 24.3 months). Excluding the postoperative deaths, the mean and median follow-up were 69.7 and 47.7 months, respectively. The status at the end of the study was: $29(30.5 \%)$ alive without cancer, $26(27.4 \%)$ deaths due to cancer, $22(23.2 \%)$ postoperative deaths, $6(6.3 \%)$ deaths due to causes not related to cancer, $1(1.1 \%)$ alive with cancer, $1(1.1 \%)$ death due to cause not reported, and $10(10.5 \%)$ were lost to follow-up, with 2 of them having recurrent disease. Thirty patients experienced recurrent disease that was local (10), distant (17), or local and distant (3). Eighty percent of the recurrences occurred within the first 2 years after surgery.

The overall survival rate (OSR) at 5 and 10 years was $52.6 \%$ and $47.4 \%$, respectively (Figure 1). The mean and median survival time for all the patients was 133.6 and 68.5 months respectively. The mean survival time for patients with vascular embolization was 9.2 months (Figure 2). The 5-year OSR for patients undergoing curative surgeries was $58.3 \%$ (Figure 3 ). The Table 4 shows the OSR according to selected variables.

\section{DISCUSSION}

Colorectal carcinoma (CRC) is one of the main causes of death in the United States. ${ }^{6}$ Despite advances in management, the rate of early diagnosis has not changed. ${ }^{17}$ Approximately $10 \%$ to $20 \%$ of CRC are advanced at the time of diagnosis. ${ }^{13}$
Radiation and chemotherapy do not cure CRC after incomplete resection. ${ }^{7}$ Surgery for recurrent CRC is rarely successful. The failure in the treatment of advanced CRC could be avoided if extended resection were considered in the first approach. . $^{15,20,21}$

Preoperative image tests could help in predicting the absence or presence of malignant invasion of contiguous structures; however, these methods should not be employed to contraindicate laparotomy for advanced colon cancer. $^{10,14}$

Moyniham first reported in 1926 an extended resection for locally advanced CRC. ${ }^{22}$ The survival rates achieved with en bloc resections are significantly higher than those obtained with operative separation of adhesions. ${ }^{1,2,12}$ During the exploration of the abdominal cavity, it is difficult to differentiate inflammatory adhesions from carcinomatous infiltration. ${ }^{23} \mathrm{Bi}$ opsies and manipulation of adhesions

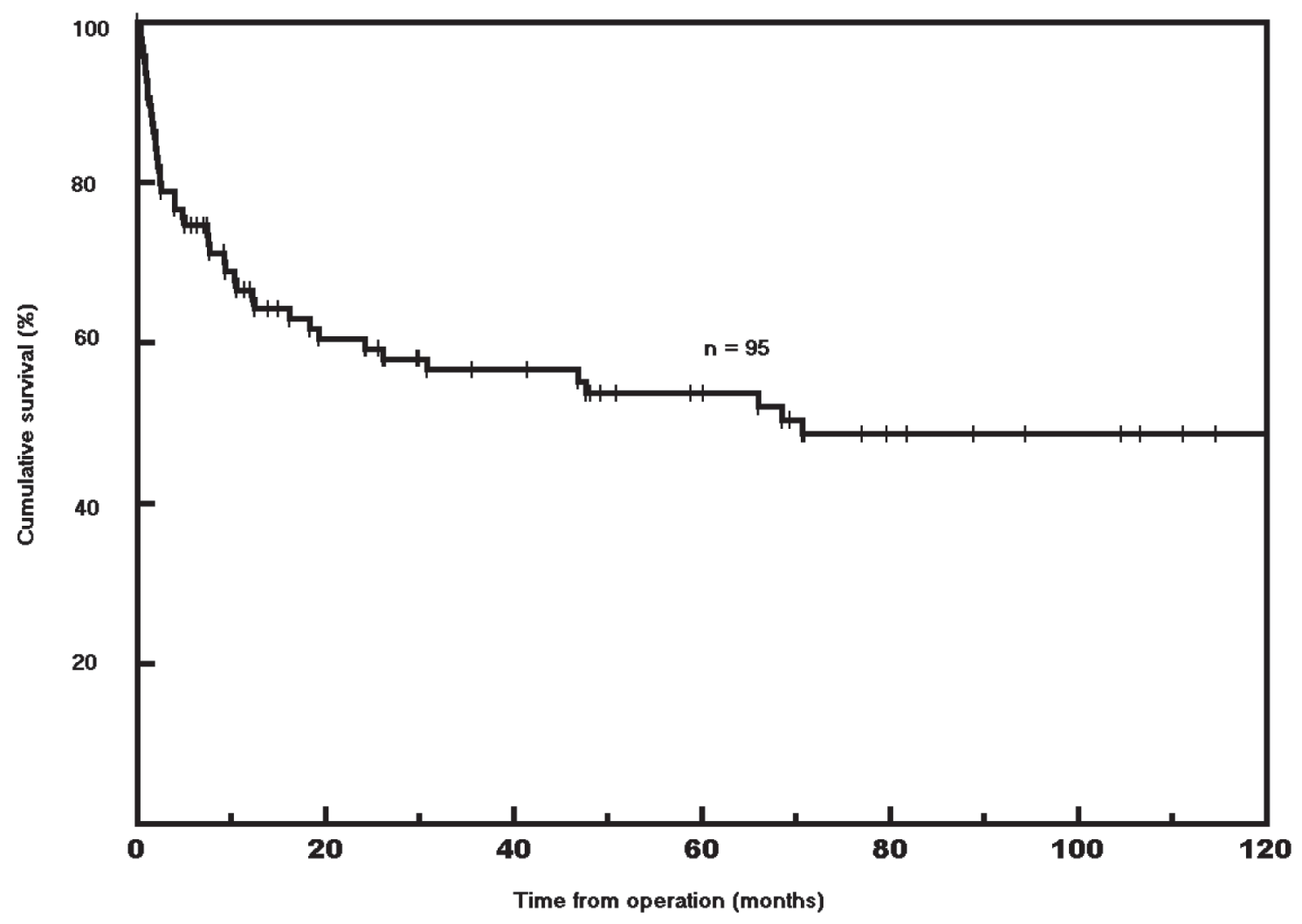

Figure 1 - Overall survival rate of patients with colon cancer undergoing extended resection. 


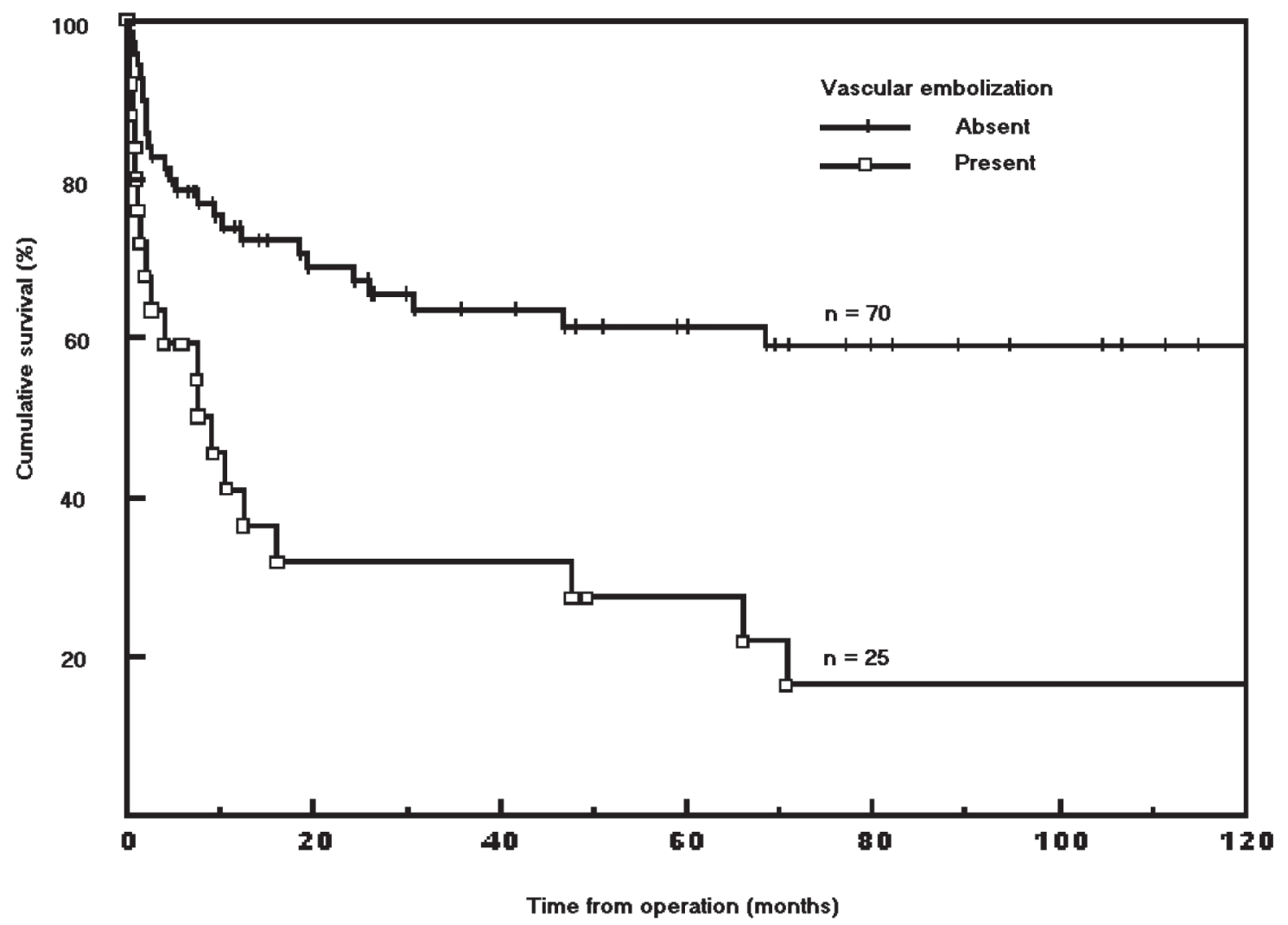

Figure 2 - Overall survival rate according to vascular embolization (absent vs present) in patients undergoing extended resection for colon cancer.

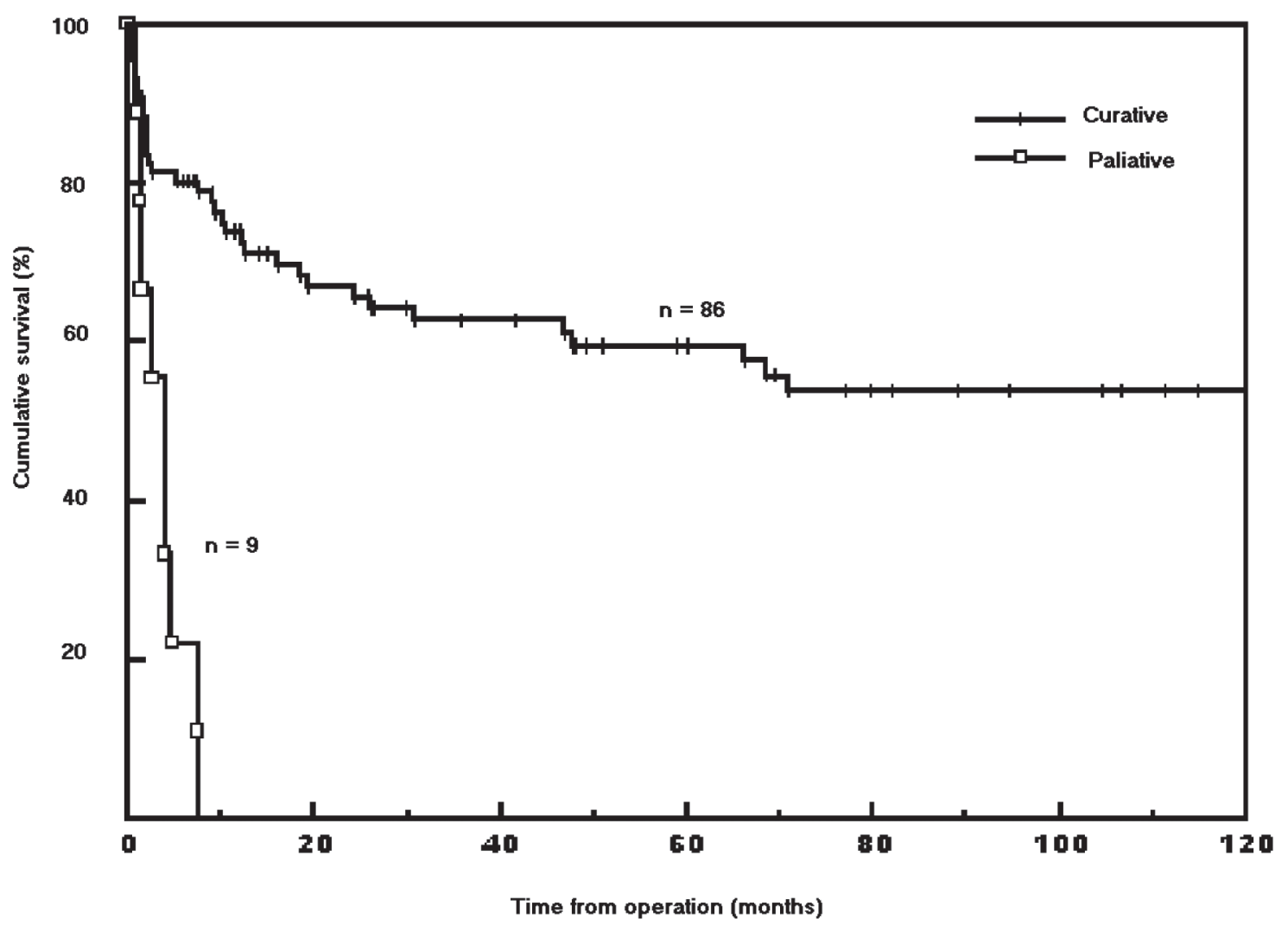

Figure 3 - Overall survival rate according to the type of surgery (curative vs. palliative) in patients undergoing extended resection for colon cancer. 
Table 4 - Five year overall survival rate according to selected variables in patients undergoing extended resection due to colon cancer.

\begin{tabular}{lcccc}
\hline Variable & Category & $\begin{array}{c}\text { No. of } \\
\text { patients }\end{array}$ & $\begin{array}{c}\text { 5-year overall } \\
\text { survival rates (\%) }\end{array}$ & P \\
\hline Type of surgery & Curative & 86 & 58.3 & $<.001$ \\
pT stage* & Palliative & 9 & 0 & .02 \\
Lymph node & pT2+3 & 46 & 63.4 & .72 \\
metastasis & pT4 & 48 & 41.3 & \\
& Absent & 58 & 57.5 & .16 \\
EC (TNM) & Present & 31 & 44.1 & \\
& Ignored & 6 & 44.4 & .33 \\
& I + II & 55 & 57.6 & \\
Differentiation & III & 26 & 52.8 & .08 \\
& IV & 7 & 14.3 & \\
Adenocarcinoma & Ignored & 7 & 53.2 & \\
subtype & Well & 21 & 42.6 & .0002 \\
& Moderate & 54 & 57.7 & \\
Vascular & Poor & 20 & 47.5 & .04 \\
embolization & Pure & 61 & 61.2 & \\
Lymphatic vessel & Mucinous & 27 & 39.4 & \\
embolization & Other & 7 & 28.6 & \\
Perineural & Absent & 70 & 61.6 & \\
infiltration & Present & 25 & 27.4 & \\
\hline
\end{tabular}

$*$ = one case excluded for analysis.

can lead to intraperitoneal seeding of tumoral cells. Hunter et al. had 69\% with local recurrence following resections with separation of adhesions and $18 \%$ following en bloc resections. ${ }^{1}$

The good results achieved in different studies regarding local control of CRC and survival rates confirm that en bloc multivisceral resections should be the standard treatment of locally advanced colon cancer for a selected group of patients. Some studies comparing extended and classic surgeries found that the presence of positive margins was associated with poor survival rates. ${ }^{8,16,24}$ There is no 5-year survival when palliative surgery is performed. ${ }^{3,5,11,14,16}$
In this series we found several pathological characteristics that were related to a better prognosis for CRC, such as $48.4 \%$ of inflammatory adhesions; $61.1 \%$ of non metastatic lymph nodes; $78.9 \%$ of grade I and II tumors; $73.7 \%$ of absence of vascular embolization; $78.9 \%$ of absence of perineural infiltration and $62.1 \%$ absence of lymphatic embolization. Tumor penetration (pT) and the lymph node status $(\mathrm{pN})$ are the most evaluated prognostic factors in several reported series of locally advanced CRC. Lymph node metastasis ${ }^{4,10,25}$ and adjacent organ infiltration ${ }^{4,5}$ have been identified as poor prognostic factors; however, there is not a consensus on this finding. ${ }^{15,16}$ On the other hand, there is consensus that positive surgical mar$\operatorname{gins}^{24,26,27}$ and nonextended resections for patients with pT4 tumors ${ }^{11,16,27}$ are strongly related to a poor prognosis.

The survival analysis based on each resected organ (Table 2) is difficult due to the high degree of association of resected organs and/or structures,${ }^{4}$ but there was no statistically significant difference in the survival of patients undergoing en bloc resection of 1 organ compared to those that had 2 or 5 resected organs, showing as in other series that the involvement of several organs should not be a contraindication for surgery. ${ }^{11}$

The significant decrease of postoperative complications and death rates from the 1950s to 1990s could be attributed to the improvement in staging methods, preoperative and postoperative care, intensive care, and the experience of surgical team. Patients undergoing surgery after 1980s had a more than $50 \%$ decrease in the chance of death related to the procedure as compared to those undergoing surgery in the early 1950s. Our data support that the experience gained with extended resections plays an important role in the outcome of patients with locally advanced CRC.

Curative extended resections are the best treatment for patients with locally advanced colon cancer. Some patients could benefit from palliative-intent procedures, but these should cautiously be indicated in patients with low Karnofsky performance status due to high rates of postoperative mortality and poor survival.

\section{RESUMO}

VIEIRA RAC e col. Fatores prognósticos em câncer de cólon localmente avançado tratado com ressecção extendida. Rev. Hosp. Clín. Fac. Med. S. Paulo 59(6):361-368, 2004.
Foi avaliado o impacto de variáveis clínicas, patológicas e cirúrgicas na morbidade e mortalidade pós operatórias de pacientes submetidos à ressecção extendida de carcinoma do cólon.
MÉTODOS: Prontuários médicos de 95 pacientes submetidos á ressecção extendida de carcinoma de cólon entre os anos de 1953 e 1996 foram revisados. Em todos os casos, além de 
colectomia, um ou mais órgãos e/ou estruturas foram ressecados em bloco devido á suspeição de invasão tumoral macroscópica. As variáveis clínicas, patológicas e cirúrgicas foram analizadas. As taxas de sobrevida global foram analizadas de acordo com o método de Kaplan and Meier. A análise multivariada foi realizada empregando-se o modelo de risco proporcional de Cox.

RESULTADOS: Oitenta e seis pacientes foram tratados com cirurgia curativa e o restante com ressecção paliativa. Invasão microscópica de órgãos e/ou estruturas adjacentes e linfonodos regionais foi encontrada em 48 e 31 pacientes respectivamente. $\mathrm{O}$ tempo de seguimento mediano, sem mortalidade pós operatória, foi de 47.7 meses. A taxa de sobrevida global em 5 anos foi de $52.6 \%$. A taxa de sobrevida global para pacientes submetidos à cirurgia curativa e paliativa foi de $58.3 \%$ e zero, respectivamente. A sobrevida mediana no grupo de pacientes com cirurgia paliativa foi de 3.1 meses. A análise multivariada mostrou que a performance status de Karnofsky fortemente correlacionou com risco de complicações pós operatórias ( $\mathrm{p}=0.01)$, e que o risco de morte pós operatória estava associada com o tipo de cirurgia e a performance status de
Karnofsky na admissão ( $\mathrm{p}=0.001)$

CONCLUSÕES: Pacientes com adenocarcinoma de cólon localmente avançados submetidos à ressecção extendida têm taxa de sobrevida global em 5 anos de $58.3 \%$ Este tipo de cirurgia pode ser empregada com intuito paliativo, mas deve ter indicação criteriosa e ser evitada em pacientes com baixa performance status de Karnofsky devido às altas taxas de mortalidade pós operatória e baixa sobrevida.

UNITERMOS: Cirurgia extendida. Ressecção en bloco. Câncer do colon. Mortalidade. Prognóstico.

\section{REFERENCES}

1. Hunter JA, Ryan JA, Schutz P. En bloc resection of colon cancer adherent to other organs. Am J Surg 1987;154:67-71.

2. Mc Glone TP, Bernie WA, Elliott DW. Survival following extended operations for extracolonic invasion by colon cancer. Arch Surg 1982;117:595-9.

3. Pitam MR, Thornton H, Ellis H. Survival after extended resection for locally advanced carcinomas of the colon and rectum. Ann R Coll Surg Eng 1984;66:81-4.

4. Heslow SF, Frost DB. Extended resection for primary colorectal carcinoma involving adjacent organs or structures. Cancer 1988;62:1637-40.

5. Eisemberg SB, Kraybill WG, Lopez MJ. Long-term results of surgical resection of locally advanced colorectal carcinoma. Surgery $1990 ; 108: 779-86$.

6. Greenlee RT, Murray T, Bolden S, Wingo PA. Cancer Statistics, 2000. CA Cancer J Clin 2000;50:7-33.

7. Metzer U, Gross TH, Honogger HP. Adjuvant treatment for colorectal cancer: "State of the art"- messages from recent trials. Eur J Surg Oncol 1995;21:341-6.

8. Gentil FC, Lopes A, Sá AOS, Cavalcanti SF, Garcia SZ, Lima EWL et al. Ressecção ampliada no tratamento do câncer avançado do cólon. Rev Bras Colo-Proct 1989;3:93-101.

9. Feuerbach S. Value of radiological techniques in the diagnosis and staging of colorectal carcinoma. Endoscopy 1993;25:10816.

10. Eldar S, Kemeny MM, Terz JJ. Extended resections for carcinoma of the colon and rectum. Surg Gynecol Obstret 1985;161:31922.
11. Gebhardt C, Meyer W, Ruckriegel S, Meier U. Mustivisceral resection of advanced colorectal carcinoma. Langenback's Arch Surg 1999;384:194-9.

12. Gall FP, Tonak J, Altendorf A. Multivisceral resection in colorectal cancer. Dis Colon Rectum 1987;30:337-41.

13. Sugarbaker ED. Coincident removal of additional structures in resections for carcinoma of the colon and rectum. Ann Surg 1946;123:1036-46.

14. Curley SA, Carlson GW, Shumate CR, Wishnow KI, Ames FC. Extended resection for locally advanced colorectal carcinoma. Am J Surg 1992;163:553-9.

15. Lopes MJ. Extended Resections. In Wanebo HJ (ed). Colorectal Cancer. $1^{\text {st }}$ ed. St Louis: Mosby 1993;318-34.

16. Izbicki JR. Hosch SB, Knoefel WT, Bloechle C, Broelsch CE. Extended resections are beneficial for patients with locally advanced colorectal cancer. Dis. Colon Rectum 1995;38:12516.

17. Weinberg DS, Brian LS. Screening for cancer: a review of current and future strategies. Sem Oncol 1995;22:433-47.

18. Reinbach DH, Mc Gregor JR, Murray GD, O`Dwyer PJ. Effect of the surgeon's specialty interest on the type of resection performed for colorectal cancer. Dis Colon Rectum 1994; $37: 1020-3$.

19. Obrand DI, Gordon PH. Incidence and patterns of recurrence following curative resection for colorectal carcinoma. Dis Colom Rectum 1997;40:15-24.

20. Polk HC. Extended resection for selected adenocarcinoma of the large bowel. Ann Surg 1972;175:892-9. 
21. Sugarbaker PH, Corlew S. Influence of surgical techniques in survival in patients with colorectal cancer. Dis Colon Rectum 1982;25:545-57.

22. Moyniham B. Abdominal Operations. Philadelphia: WB Sauders, 1926.

23. Sugarbaker ED, Wiley HM. The significance of fixation in operable carcinoma of the large bowel. Cancer 1959;12:681-7.

24. Lehnert T, Methxer M, Poltok A, Schaible S, Hiuz U, Herforth C. Multivisceral resection for locally advanced primary colon and rectal cancer in analysis of prognostic factor in 201 patients. Ann Surg 2002;235:217-25.
25. Rowe VL, Frost DB, Huang S. Extended resection for locally advanced colorectal carcinoma. Ann Surg Oncol 1997;4:1316.

26. Spratt JS, Watson FR, Dratt JL. Characteristics of variants of colorectal carcinoma that do not metastasize to lymph nodes. Dis Colon Rectum 1970;13:243-6.

27. Poeze M, Houbiers JGA, van de Velde CJH, Wobbes TH, von Meyenfeldt MF. Radical resection of locally advanced colorectal cancer. Br J Surg 1995;82:1386-90. 